Article

\title{
Levinas and the "Matter" of Poverty
}

\author{
Timothy W. Rothhaar
}

Department of Philosophy, Marquette University, 1250 W Wisconsin Avenue, Milwaukee, WI 53201-1881, USA; Timothy.Rothhaar@Marquette.edu

Received: 31 October 2018; Accepted: 26 November 2018; Published: 28 November 2018

check for updates

\begin{abstract}
Poverty" is a term Levinas uses to describe the face-to-face encounter and the Other all through his corpus. Scholars regularly use this term, but no research has shown its origin nor that Levinas has a concept of poverty. This paper addresses both of those questions through an analysis of an early reflection on Judaism and the relevant sections of his Totality and Infinity. In the process, I argue for an alternative interpretation of Levinas's ethical phenomenology on the basis of poverty concluding with some suggestions on how a Levinasian spiritual poverty can aid the pursuit of justice.
\end{abstract}

Keywords: ethics; politics; poverty; vulnerability; development ethics; humanism; continental philosophy; phenomenology; economics

\section{Introduction}

In the first section, I will establish Levinas's concept of poverty as formed in an early reflection on Judaism. In the second section, I will provide an account of Levinas's use of this concept of poverty in his Totality and Infinity text within the confines of my relationship to one other person. In the third section, I will address his use of this concept within the confines of my relationship to all other people. In the fourth section, I broach the impact of my interpretation of Levinas's ethical phenomenology in the development ethics of Ananta Giri with a suggestion to where a Levinasian spiritual poverty can lead us in creating more just communities.

\section{Difficult Freedom: Material Poverty and the Other}

Levinas's commentaries on sacred Jewish texts, the Talmud and the Torah, reveal material poverty as a major source of his ethical phenomenology, including the intertwining of religious and political ideas. Since knowledge of the Talmud is a "necessary condition of Jewish thought," it is essential to begin here if I am to present Levinas's use of material poverty faithfully (Levinas 2012, p. 60). In section two of Difficult Freedom, a collection of his essays on Judaism, he offers a commentary on selections of the Talmud concerning messianism. I will focus on just the first commentary of Talmudic tractate Sanhedrin 99a using his discussion of messianism to frame his application of material poverty in Totality and Infinity. Levinas explains that Jewish messianism is popularly defined as the coming of a person, typically a leader, to end political violence and social injustice. This is known as "apocalyptic messianism" because it refers to this fundamental change in the world in accordance with prophecy. A second definition of messianism excludes the role of a specific person and instead preferences moral reason instead of prophecy to bring about change (Levinas 2012, pp. 296-97). This is called "rationalist messianism," and it is what Levinas emphasizes in his readings of Sanhedrin 99a. He prefers rationalist messianism for two reasons. First, to draw attention to the concrete situation of sociopolitical injustice all over the world in its various forms to see what humankind can do to better its quest for world peace. Second, to establish the theoretical ground for the existence of the State of Israel while encouraging the Jewish people to embrace Zionism in preparation for the messianic era. 
The messianic era is a future time wherein peace, justice, and solidarity reign supreme over the earth. The specifics of how this era comes about, and whether it ends political violence and social injustice, is what intrigues Levinas about tractate Sanhedrin 99a. His commentary begins with a passage:

All the prophets prophesied [all the good things] only in respect of the messianic era; but as for the world to come, "the eye hath not seen, O Lord, beside thee, what he hath prepared for him that waiteth [sic] for him." (Levinas 2012, p. 60)

Also called the "future world," the world to come is the messianic era, and its nature is debated in the tractate by two rabbis. Their positions on the messianic era are contrasted by how they conceive the relation to the Other. The "Other" is my neighbor, another human being in need of help or kindness. The capitalization of the " $\mathrm{O}$ " is used to differentiate the individual human being from anything that is not human (e.g., a stone) or a group of humans. Non-humans and groups of humans are distinguished by a lowercase "o" other. I am using the basic distinction here throughout the paper, so I will not broach the difficulties of translating Levinas's French as noted by Dino Galleti (Galetti 2015).

For the first rabbi, R. Johanan, Levinas tells us the messianic era is not the end of all history, as if everything permanently stops, but the fulfillment of Jewish prophecies both political and social. In general, the political concerns the power of the State to exercise violence against its own people, other States, and the people of those States. The social concerns the relations between two or more individual people regardless of State affiliation. R. Johanan holds that the messianic era will end both political violence and, in Levinas's words, "the social injustice, the power the rich hold over the poor" to bring about the fruition of all prophecy (Levinas 2012, p. 60).

It should be noted that Levinas interprets that specific injustice to be all social injustice. Note that he does not say " $a$ social injustice". The article is "the" - the social injustice is oppression of the poor. Passages like these indicate that references to poverty and the poor in the Talmud and Levinas's commentary are surely not metaphorical. They refer to concrete, material poverty and literal poor people.

Nevertheless, R. Johanan's messianic era is individualistic in that it does not consider the greater good of society, on Levinas's reading, because it does not concern itself with the social, that is, with other people. Rather, R. Johanan's future world prefers its own interiority to the detriment of others. Interiority is Levinas's term for the ego, or the self. It is me as I am individuated from all other people according to my thoughts, memories, labor, possessions, and habitat (Levinas 1969, pp. 53-60). It is an inner, private place where only I exist. One might say Levinas finds in the Talmud here the self/Other distinction, and he asserts that the self's inner world is in fact not Jewish because Judaism "teaches only the truths that concern the Good [sic] of the community and the public order," like the end of political violence and social injustice (Levinas 2012, p. 61). Ending these sociopolitical injustices prompts for R. Johanan "a life above the political and the social" in what he deems "the spiritual life" (Levinas 2012, p. 62). The spiritual life is how one lives in relation to others. R. Johanan's understanding of the spiritual life includes "an end to economic [instability]" (Levinas 2012, p. 62). What he means exactly by that is unclear as even Levinas admits it could mean a life of pursuing "knowledge or artistic action" outside one's relationship to other people, or something else altogether (Levinas 2012, p. 61). Regardless, what is clear is that R. Johanan's spiritual life is ultimately one of individual pursuit in a messianic world where the end of political violence and social injustice has ended a need for one to relate to others.

The spiritual life is quite different for R. Samuel, who has said in contrast, "this world differs from [that of] the days of the Messiah [the future world] only in respect of servitude to [foreign] Powers [sic], as it [the Torah] says: For the poor shall never cease out of the land (Deuteronomy 15:11)" (Levinas 2012, p. 61). Servitude is synonymous to political violence, an example of which is the Jewish enslavement by the Egyptians. R. Samuel's messianic era embraces an end to only political violence, not an end to social injustice (i.e., oppression of the poor). To end social injustice is to end R. Samuel's 
concept of the spiritual life: communion with my neighbor. Communion is intimate fellowship, and for R. Samuel it "cannot be separated from economic solidarity with the Other" (Levinas 2012, p. 62). Economic solidarity is communion with the Other on the basis that I share my material resources with her. The material resource I give to the Other links us together in commonality: what is mine is now ours. We share it. A person can more readily give in the absence of political violence for it is violence that often destroys community, but the absence of material poverty would nullify sharing altogether. Its absence would make sharing meaningless, but that does not mean the poor ought to exist just so the "rich have the messianic joy of nourishing them" (Levinas 2012, p. 62). Material poverty means something much more radical for R. Samuel: that "the Other is always the poor one [and that] poverty defines the poor person as Other" (Levinas 2012, p. 62). This first part-the Other is always the poor one-is a bit odd.

The Other, as the poor one, is in need of assistance. One kind of assistance is an economic boost (e.g., sharing a resource) in that the Other cannot presumably help herself. The Other, as the poor one, needs me to help her. Material poverty, then, bridges me to the Other because it is on the basis of material poverty that I share in the first place. There would be no economic solidarity in giving were the Other and I both rich — that is, not needing assistance-for we would have no need to relate. Because one can only relate to the Other in sharing, one must never meet the Other "empty-handed," that is, without anything to offer assistance (Levinas 2012, p. 62). That is why the Other is always the poor one for R. Samuel: she is in perpetual need of assistance. Surely, though, anyone who needs assistance is not necessarily materially poor, yet needing assistance seems a kind of poverty. In this broader sense of poverty, the fact that the Other needs help at all, not simply in reference to economics, suggests a second kind of poverty, namely, spiritual poverty.

Spiritual poverty is a need of assistance at the spiritual level. Specifically, it is a state of dependence on another person for the incorporeal necessities of life (e.g., community) in such a way that one cannot provide these necessities for oneself. Something spiritual is incorporeal-it cannot be touched with human hands. In the case of economic solidarity, I cannot touch the community I form with the Other the same way I can touch the material resource (e.g., food) I share. What I share with the Other is now twofold. Economically, I share a material resource with the Other for the survival of the body, which in turn generates sharing a spiritual resource (i.e., solidarity) for the survival of our relationship.

One must always be ready to relate to the Other and thereby always be ready to give something. This readiness to give implies that my relation to the Other will "always be an offering and a gift" which in turn breeds solidarity (Levinas 2012, p. 62). This gift, the sharing or giving of a resource as noted above, is the primary means of relating to one's neighbor in the spiritual life of R. Samuel. His conception of the spiritual life, however, can be construed as moral responsibility for the Other and not a kind of abandonment of the world or mysticism.

Moral responsibility for the Other, and its connection to both poverties, alongside rationalist messianism and the self/Other relationship within this Talmudic commentary, frame Levinas's use of poverty in Totality and Infinity. The poor person and material poverty of R. Samuel are converted into a metaphor for spiritual poverty to explain my relation to the Other, which I argue is the root of Levinas's ethical phenomenology. Having shown Levinas's interpretation of this tractate, I will now argue that he appropriates it for his ethical phenomenology.

\section{Totality and Infinity: The Face-to-Face Encounter}

The purpose of Totality and Infinity is to describe the experience of moral responsibility for the Other. In order to understand how Levinas uses "poverty" in this work, and its intertwining with the experience of moral responsibility, I must first explain what Levinas means by "the face". It would be an understatement to say the face does a lot of work for Levinas, and I am not interested in tracing out in detail all of the ways he uses it to describe the numerous dimensions of human relationships. Rather, because it is a tricky term, I would like to clarify its meaning as it pertains to this paper. 
A technical term is one with a fixed meaning that never changes, or perhaps changes only slightly, throughout a philosopher's corpus. In this sense, Levinas does not have any technical words for what he means by "the face" because a technical term has one specific meaning, and Levinas uses many words for "face". In an ordinary sense, "face" is a synonym for countenance, the literal look and expression of a human being. What Levinas means by "the face," however, he also means by "signification" and "truth" (Levinas 1969, pp. 60, 204). The exact meanings and implications of these terms as "the face" for Levinas are irrelevant for this paper, suffice it to say they are analogous for something else, and in this regard "the face" is a metaphor. For instance, when I look at another human being's countenance I see an expression, whether happy, sad, angry, or somewhere in between. I can describe this expression with any number of words and phrases, and I can make out the particularities of another's body (e.g., the color of the eyes or wrinkles), but Levinas argues there is more to a person than just physical features. He adopts a metaphorical meaning of "the face," which refers to something beneath my visual perception. That something is the humanity of the Other. The humanity of the Other cannot be encapsulated in just one term, or even many terms. It is, as Aryeh Cohen says, "beyond my ability to completely assimilate into my preordained categories [of understanding the world]," hence Levinas's lacking a technical term for the face (Cohen 2015, p. 416). For this reason, I will be using the term "face," and not any of Levinas's synonyms for it, and for this paper it will mean the humanity of the Other. Now, the experience of the face comes in the context of the face-to-face encounter.

The face-to-face encounter is a one-on-one, in-person interaction with the Other (Levinas 1969, pp. 79-81). Levinas uses the term "encounter" because meeting the Other is an event. It is a unique happening that can never be repeated in exactly the same way. In this sense, the encounter reflects the inadequacy of describing the face because both prevent me from "placing [them] into a conceptual box" (Cohen 2015, p. 416). Unlike one's literal countenance, there are no words to adequately describe my experience of the face of the Other. At the encounter, I experience the face as "the vulnerability and need of [the Other] which incurs in me a [moral] responsibility ... to respond to that need" (Cohen 2015, pp. 416-17). R. Samuel, whose moral response to the Other is tied to economic solidarity, is responding to economic vulnerability. For Levinas, the moral response to the need of the Other in the face-to-face encounter is tied to the Other's humanity-the response is to her human vulnerability. Her material poverty signals a spiritual poverty. In this way, vulnerability serves as the link between the self and the Other at the spiritual level.

As explained in section one, the spiritual life has different meanings for R. Johanan and R. Samuel. Levinas is adopting R. Samuel's concept of the spiritual life because, unlike R. Johanan, Levinas longs for communion with the Other in moral responsibility, a spiritual connection. As the face-to-face encounter shows, I am made aware of my moral responsibility for the Other in experiencing the Other's needs and vulnerability as spiritual poverty. The overlap between Levinas and R. Samuel's notions of moral responsibility lies in R. Samuel's understanding of material poverty. To demonstrate this common ground, I argue that this responsibility comes about in the spiritual poverty of the face beginning with language.

Section one, subsection five, "Discourse and Ethics," is where Levinas discusses the relation with the Other as conversation (Levinas 1969, pp. 72-76). Conversation is a particular type of face-to-face encounter, and while the Other is separate from the self according to the Other's needs, the self and Other relate through what they speak in language. Language originates as the first moral response to the Other. Recall R. Samuel's conception of moral responsibility: communion with the Other in our economic relationship. With that being said, language is not necessarily words. My response to the Other can take the concrete form of giving a material resource. When I share my goods, I am "speaking" directly to the Other that I do not meet her empty-handed. As the face is a metaphor for the Other's humanity, "speaking" is a metaphor for communication of what is inside of me. In "speaking" to the Other, language is an expression of my interiority, for when I speak, I become exterior-my language conveys what is inside of me immediately to the Other and the outside world. What is really inside of me, and the Other, is poverty. 
It is not difficult to imagine a beggar naked or close to it. R. Samuel does not make explicit mention of this image in the Talmud, but Levinas makes metaphorical use of nakedness in this section of Totality and Infinity. To be naked, as a metaphor, is to be without adornments, that is, without particularities about one's humanity (Levinas 1969, p. 74). Particularities add detail to a thing in addition to the purpose for which it was made. An example is a wall. It is naked when it serves only its purpose of separating one space from another. Beautiful things, like wallpaper, are later added onto the wall to point it beyond its mere function. It is "clothed" in some sense. This gives the wall a place in the whole schema of, for instance, interior design. I no longer need to relate to the wall only as a separation device. I can relate to it as an object that gestures me to seek aesthetic things. In not relating to the wall strictly in its original purpose of separating spaces, it is no longer nude because I have produced a new meaning in "clothing" it. I cannot, however, give new meaning to the Other.

The Other is not my object to adorn as I see fit. The Other comes to me as bare, vulnerable, abstracted from all the details of the world, including the future world of rationalist messianism. I do not address the Other the way I "address" a wall. My addressing the Other, and so my relation to her, comes about through language. Language undoes "new meaning" because it does not relate to the adornment of things, but to the nudity beneath the adornment: I am not speaking to the bodily particularities of the Other, but to the Other's humanity in her nudity. For Levinas, that nudity is the face, for "nudity always refers in one way or other to the nakedness of the face" (Levinas 1969, p. 75). Recall that language communicates immediately with the face of the Other- "immediately" because it breaks through all the "adornments" covering the Other (e.g., the color of the eyes or wrinkles). The problem here is that I do not relate to the face the same way as I relate to a wall, or any object, because the face is not an object of knowledge. I cannot "know" the Other in a comprehensive way as I know a wall to be a separation device. Likewise, a wall cannot be poor in any humanitarian sense, but the face is poor, in that the material nudity of a beggar corresponds to the inner nudity of the Other's humanity as spiritual poverty. Just as the beggar depends on me to not meet her material poverty empty-handed, she also depends on me to respond to the spiritual poverty of her face. This response is linked to Levinas's own description of the face as that of poverty.

He tells us "the nakedness of the face is destituteness" (Levinas 1969, p. 75). Destitution is a synonym for material poverty. I discussed the nakedness of the face as a metaphor for lacking particularities, and Levinas's use of destitution here suggests it, too, is a metaphor. This raises the question as to why Levinas insists the face is "destitute". The face is destitute because, like the material nakedness of the beggar and the metaphorical nakedness of the Other, destitution is a metaphor for the face's powerlessness. It is powerless to prevent its own poverty, unprotected against the elements of the human condition, including death. Similar to a beggar hungry for food, and needing me to respond to her, the Other is "hungry" for my response, hungry for me to give to her a "shelter" from the harshness of the human condition with my response. The hunger and nakedness encapsulating material poverty exist at the spiritual level of the Other in needing me to respond to her face: "To recognize the Other is to recognize a hunger," Levinas says (Levinas 1969, p. 75). This hunger is spiritual poverty, and it is affirmed by Levinas when he says, "Existence [in-itself] is, in the world, a destitution" (Levinas 1969, p. 75). The world is where I encounter the Other, and so her existence is part and parcel of my own when I recognize her as the one to whom I ought to share my resources, material or spiritual. "To recognize the Other is to give," Levinas adds, and like R. Samuel, this response to the spiritual poverty of the face embodies the "spiritual life" characteristic of moral responsibility for the Other (Levinas 1969, p. 75). That response is the giving of a resource in a manner parallel to R. Samuel's economic relation, something shareable between two people. Unlike R. Samuel's material resource, however, the giving to the spiritual poverty of the face is not consumable, for the gift is an offering to produce a community. The material resource, though necessary for survival, is symbolic of that shared world. Yet, you and I are not the only ones who share this world. There are multitudes of people who share it. Levinas must account for these others. 
In this section, I argued that R. Samuel's poor person and material poverty are foundational metaphors for the spiritual poverty of the face in Levinas's ethical-phenomenological relationship between the self and Other. I argued that this relationship is, phenomenologically, found in the face-to-face encounter and is enacted through language and response in all its intricacies. I will now argue that Levinas continues his use of poverty in section three, subsection six, "The Other and the Others," of Totality and Infinity, this time in reference to what he calls the "third party" (Levinas 1969, pp. 212-14).

\section{Totality and Infinity: The Third Party}

After laying out the face-to-face encounter, Levinas works through a philosophy of immanence wherein he describes what one can talk about outside the ethical relation as it pertains to interiority (Levinas 1969, pp. 109-86). He returns to the ethical relation afterward and discusses it, not in reference to one other person, but to what he calls the "third party". Like the face, "third party" is a complicated term, the specifics of which change over the course of Levinas's work (Levinas 1978, pp. 153-62; Levinas 1987, pp. 25-45). I will not discuss the nuances and changes he makes to it over time, but there is a core meaning intact, which I will now clarify.

The third party is not the singular Other of the face-to-face encounter, but all others outside of it. The third party is society, or as Levinas says, "the whole of [humankind]" (Levinas 1969, p. 213). It is named as such because it does not stand in direct relation to the first-person $m e$, the self, nor to the second-person "you" of the Other. The third party is "third" because it has the grammatical function of a "they," that is, people who are over there away from you and I. I experience the third party as a crowd-a bundle of others whose needs overwhelm my ability to satiate. I am not in as personal a relationship with the third party, but the third party neither concerns itself with the interiority of the self, nor the moral responsibility for the Other, nor their relationship. Its concern is the carrying out of justice. As one can deduce from the discussion of Difficult Freedom in section one of this paper, justice is social responsibility: the concern for the well-being of all others, especially as concerns the oppression of the poor. One could say morality is always for the Other, whereas justice is for everyone else. This "everyone else" is the third party because its concern is with the relationship between more than two people. When discussing Levinas, one must keep in mind these levels of morality and justice because they often intertwine and refer back to one another much like they do in the section "The Other and the Others" which I will now consider.

Levinas begins this section with a word on language. Language, analyzed above in section two as an expression of interiority, is here posited as "the presence of the face" (Levinas 1969, p. 213). The "presence" of the face is the fact that the Other is in-person with me in the face-to-face encounter. Just as I "speak" to the face of the Other in not meeting her empty-handed, so too, does the face's presence "speak" back to me. The face speaks a reminder that there are other people in need of solidarity, suggesting that a potential problem with the face-to-face encounter is forgetting the rest of the world. I can become so absorbed in the one-on-one relationship that I forget other people exist, but the face reminds me that this is not so, for as Levinas declares, "the third party looks at me in the eyes of the Other" (Levinas 1969, p. 213). Like the language which breaks through the "adornments" covering the Other, the face of the Other "speaking" to me brings to mind all the others in the world also in need of my response. It is not as though the Other comes to me-or I to the Other-we have our encounter, then go our separate ways. Rather, the third party is always lurking amidst our encounter, and I am reminded that there are those others excluded from this one-on-one relationship. I owe them something parallel to the moral responsibility I owe the singular Other. When I share a resource with the Other, as in R. Samuel's spiritual life, this offer inadvertently extends to all others as the third party because, difficult or not, I can make that same offering to all people. That offering, which parallels moral responsibility, is justice as it comes in the form of language. As Levinas says, "language is justice" (Levinas 1969, p. 213). 
Established in section one of this paper, the social injustice for Levinas is the oppression of the poor because it reflects the imbalance of power the rich have over the poor as an economic instantiation of not "speaking" or responding to the face of the Other. Like R. Samuel, Levinas agrees the material poor should not exist just so the rich can save them from their material conditions: When I "speak" to the Other, I speak to her nakedness. The just response is the one that speaks. He continues this section by shifting from language's reference to the third party to a discussion of metaphorical nakedness and material poverty in the third party. Levinas says earlier in Totality and Infinity "the nakedness of the face is destituteness," which I discussed as a metaphor for the face of the Other lacking particularities (Levinas 1969, p. 75). Here, Levinas makes the same claim, with some additions, saying,

The face in its nakedness as a face presents to me the destitution of the poor one ... [who] presents [herself] as an equal. [Her] equality within this essential poverty consists in referring to the third party, thus present at the encounter, whom in the midst of [her] destitution the Other already serves. (Levinas 1969, p. 213)

The previous connection made between the metaphorical nakedness of the face and the material poverty of the poor person was stated in relation to the self and Other, but here the connection is stated in relation to the third party, so it must be explained in relation to the third party.

The notion of equality Levinas mentions above pervades his mature texts where his discussion of politics and the political come to the fore of his thinking, but its importance for my discussion is that the Other and the third party are equal in "essential poverty" (Levinas 1978, 1993, 1999). The poverty is "essential" because, as I explained in the first section in relation to R. Samuel, poverty must be present in the Other or else the Other is not an Other. Since the third party is all others, it is only a matter of extension to see that all others are also essentially poor in virtue of their being Other. The singular Other is equal to all others of the third party because both are spiritually poor-they need my response, whether I "speak" at the level of morality or justice. That is the essential poverty Levinas is referring to: the spiritual dependence, characterized by the need for a response, that makes the Other human. Levinas thus adds the face- - the humanity of the Other-into the definition of spiritual poverty. I call this addition "Levinasian spiritual poverty".

He adds, "the presence of the face ... is a destituteness" (Levinas 1969, p. 213). Recall in section two of this paper that Levinas uses "destitution" as a metaphor for the powerlessness of the face to prevent its own poverty. The presence of the face now speaks that I am responsible for each individual Other and the third party in their essential spiritual poverty. It is not a difficult stretch to then see how R. Samuel's Other is actually the singular Other of the face-to-face encounter and all others of the third party. As all people are spiritually poor, I am responsible for them in morality and justice. I discussed the moral response in sections one and two, but the just response, as one of language, is tricky because I am still responsible for the needs of the Other. I have only so many resources. It is here, at the level of resources, that the issue of justice is tied intimately to the issue of material poverty.

Having shown the connection between the self, the Other, the third party, and material and spiritual poverty, I will now offer a suggestion on how my alternative interpretation of Levinas's ethical phenomenology impacts development ethics.

\section{Material and Spiritual Poverty in Development Ethics}

Development ethics is an area of inquiry concerned with incorporating ethical reflection into discussions about socio-economic progress in underdeveloped countries. Its focus is "[material] poverty, human security, violence and the plight of the vulnerable," taking into consideration the means, ends, and values involved in jumpstarting small economies (Giri 2005, pp. 46-61). Its relevance for this paper lies in its intertwining of the material and spiritual poverty of the Other and third party in an attempt to encourage laws that satisfy people's material needs while respecting their humanity. Ananta Giri is a development ethicist using Levinas to address the plight of the material poor while neglecting Levinasian spiritual poverty, that is, the face of the Other as it is dependent on 
me for a response. I would like to make the suggestion that my interpretation of Levinas's ethical phenomenology on the basis of poverty adds to the conversation of addressing the concern for the material poor in development ethics by incorporating Levinasian spiritual poverty.

Giri argues that individual citizens and countries need to become economically self-determinate so that they can more effectively assist poor people and their countries to do the same. At the individual level, self-determination means that a citizen is not dependent on other citizens through social programs or one-on-one charity measures (e.g., begging for money) to survive. At the national level, self-determination is the independence of a country from needing foreign aid to begin competing in the international market. By emphasizing their own needs over the needs of others, both individual citizens and countries learn to function in isolation, similar to the inner world of the self in Levinas's notion of interiority.

Like interiority, one lacks contact with the Other in the face-to-face encounter through this process of self-determination. Giri says, "this task of self-[determination] as the self looks up to the face of the Other has been unfortunately totally ignored by the ethical philosophers of the Other such as Levinas" (Giri 2005, p. 54). By "looking up," Giri is not maintaining that Levinas ignores the face of the Other, but that Levinas subordinates the self's needs in favor of the Other's needs. Giri wants to put the self center stage, and his point is that without the self there is no one to give a resource to the poor. As a result, "the most useful thing a [person] can do for others is to work at [her] own improvement" because an improvement for the self is an improvement for the Other (Giri 2005, p. 51).

Giri recognizes that an overemphasis on self-determination, however, can lead to the problem of not "recognizing the face of the Other" at all, a moral failure (Giri 2005, p. 55). In the process of self-improvement, he recommends sharing food with the materially poor because it "can be a concrete act of recognizing the face of the Other ... as Levinas urges us to do" while staying consistent with his ethic of self-determination (Giri 2005, p. 56). Like R. Samuel, Giri agrees I must share my resources, like food, with the Other in moral responsibility. The Other's economic independence cannot boost itself without some necessary input from me, and Giri is sensitive to this need in his suggestion that I share resources with the Other. As a materially poor person is dependent on my not meeting her empty-handed, Giri adds that all citizens and countries need other people and countries to survive:

Development ethics reiterates the need for sharing our resources and abilities with the poor.

Development ethics pushes the ethics of the Other further towards recognizing the face of

the poor as an extremely vulnerable Other. (Giri 2005, p. 56)

In addition to recognizing the face of the Other at all, Giri identifies the face as the poor one, "an extremely vulnerable Other." The intertwining of the Other and material poverty slows down Giri's self-determination ethic because of the shift from the self to the Other. He almost forgets about putting the self first, but quickly asserts that "[sharing resources] are also not meant to perpetuate an eternal cycle of dependency among the poor," but that our moral responsibility is to lift the poor people and countries of the world into a state of economic independence (Giri 2005, p. 56). It is this point of Giri's self-determination ethic that can benefit from Levinasian spiritual poverty in understanding how to morally respond to the poor as Giri's "extremely vulnerable Other".

Self-determination, on the way to both individual and national economic independence, is marred by material poverty. Self-determination is about empowerment, standing on one's own, and though Giri holds that my responsibility is to lift the material poor out of their poverty into economic independence, that same poverty renders one powerless about one's own economic situation. The material poor need me to become economically self-determinate to help them do the same, but Giri does not discuss self-determination as a spiritual need. He only discusses self-determination at the level of material poverty. Like the need found in the material poverty of R. Samuel's economic relation, the resource that "speaks" to the Other is characteristic of a spiritual need, a spiritual powerlessness, and a need at the spiritual level is a spiritual poverty.

Recall in section two of this paper the discussion in Levinas of the destitute face as powerless against the elements of the human condition. The destitute, powerless face has a spiritual poverty 
"hungry" for a moral response from me that "speaks" as a resource. In this sense, Giri's desire for self-determination, as separation from the Other in the economic relation, is a spiritual poverty. Self-determination is a dependence on the Other for an incorporeal resource that one cannot give to oneself: freedom. Freedom is the product of economic independence. It is the ability to choose one's destiny apart from consideration of the Other's needs, whether as an individual or as a country, much like Levinas's interior self. It is the essence of Giri's self-determination and could be argued that, like Levinas's interior self, citizens and countries could survive on their own, but simply choose not to for the sake of ease or comfort. This line of argumentation is incorrect. Rather, interiority is a question of preference: the self, like a country, prefers itself over all others. It is the center of its own universe with the power to do as it pleases in its freedom, yet it can only do what it pleases in relation to others-the Other or the third party.

Here, Giri briefly parallels with Levinas's ethical phenomenology. The powerless material poor of R. Samuel correspond to the powerless material poor, the Other or the third party, of development ethics in that each are dependent on me to respond to their plight. Likewise, the powerlessness of the face's spiritual poverty corresponds to the notion that a lack of self-determination in a poor person or country is a spiritual poverty: both are dependent on me to provide resources they cannot give to themselves, be it at the individual or national level. In other words, R. Samuel's not meeting the Other empty-handed parallels the resource-giving in development ethics. To consistently not come empty-handed, the self must be subordinate to the Other, something Giri wants to avoid. He does not hold the bond engendered by my economic relation to the Other in as high esteem as does Levinas because sharing too many resources, for Giri, makes the Other dependent. He splits from Levinas on this point.

The benefit of sharing resources in the economic relation comes from the parallel between material and spiritual poverty in the beggar and face of the Other. Levinas takes for granted on the basis of revelation that Deuteronomy 15:11 is correct that "the poor shall never cease out of the land," that is, the material poor will never cease to exist. Whether or not that is true is a moot point because the spiritual poverty of the human condition found in the vulnerability of the face will exist as long as humankind exists. The spiritual poverty of the human condition parallels the material poverty of R. Samuel's beggar-the Other is always in need of something. Giri, however, does not go the extra mile in claiming that we are always spiritually poor, always dependent on each other for everything. He recognizes the face of the poor as an extremely vulnerable Other, but stops short of declaring that this poverty never ends because he does not incorporate a consideration of spiritual poverty, specifically Levinas's kind, into his analysis. He simply wants us to balance self-determination with recognizing the face so we do not become immoral. Self-determination, then, leads us to developing our own independent and national economies on our own terms obtaining the richness of freedom Giri wants.

It might be objected that there is a certain "richness" of spirit in being able to provide for another. There is a "richness" of, say, sharing something like one's happiness with another that might encourage seeking a better economic situation. As Levinas says in Difficult Freedom, however, the poor should not be poor just so the rich can enjoy nourishing them. I would add that the nourishment, matter or spiritual, is not necessarily a response either. The "richness" of sharing something like happiness is not so much a response to the Other, as much as it is one's state of mind. Happiness does not automatically create a shared world between two people or justice for the third party. Economy, however, does create a shared world.

Development ethics takes into account all others, individual and national, influenced by a single economy. The international economic market of development ethics parallels Levinas's third party, the whole of humankind seen in the eyes of the Other as noted in section three of this paper. One country can respond to the needs of another by any concrete means (e.g., offering financial aid) the same as any citizen responding to the Other in the face-to-face encounter. The moral response of one individual citizen or country to another, though, necessarily implies all other citizens, countries, 
and citizens of those countries as the third party lurking in the background-what one citizen or country does for another impacts all the rest when helping to produce freedom.

Giri understands this situation, which is why he takes the time to note that "[sharing] reiterates the need for realizing the integral link between ... food and freedom" (Giri 2005, p. 56). As discussed, freedom is essential to the self-determination of an individual citizen or country. The link between food as a material resource and freedom as a spiritual resource, noted earlier in this section, parallels the connection between the response to the material poor in Levinas's Talmudic commentary and the response to the destitute face in his ethical phenomenology of Totality and Infinity: both are in constant need because both are perpetually poor, be it material or spiritual poverty. For this reason, Giri cannot solve the development-ethical problem of relating to the poor as "an extremely vulnerable Other" without Levinas's spiritual poverty. Giri's position is reminiscent of R. Johanan: end the dependent social relationship and do as you please. Levinas's reply is that community is formed by responding to the Other's spiritual poverty, which includes her humanity, through the material resource (Levinas 1969, p. 214). While Giri relates to the vulnerable Other's material poverty in sharing food, he ultimately fails to recognize the poverty of the human condition underlying material poverty. The freedom he wants for the material poor, both individually and nationally, will not last because self-determination is in constant need of relation to the Other.

The implication of this distinction between material and spiritual poverty at the Talmudic, ethical-phenomenological, and development-ethical levels is that incorporation of a Levinasian spiritual poverty of the face into those conversations could influence new foreign policies and national laws to reflect both kinds of needs in the material poor. Only then would the material poor be seen in their full humanity, regardless of their ability to self-determine or not. Thus, the insight of Levinasian spiritual poverty that development ethics needs is that one does not simply share material resources, but one's own humanity in the attempt to create a world embodying rationalist messianism: peace, justice, and community.

\section{Conclusions}

The analysis of an early reflection on Judaism, coupled with its application in Totality and Infinity, shows that there is a concept of poverty embedded in Levinas's ethical phenomenology. This concept is rooted in two rabbinic uses of messianism, apocalyptic and rationalist, as found in the Talmud with reference to the Torah. These messianisms each refer to material poverty and poor people. Levinas inherits this notion of poverty when describing the face-to-face encounter, using material poverty as a metaphor for the Other's spiritual poverty-her dependence on me for a response. In experiencing the Other as dependent on me for a response to her vulnerability, I realize that all Others—the third party-are equally vulnerable, but I cannot respond to every Other's need (justice) without exhausting my own resources. Levinas's addition of the face into the definition of spiritual poverty gives us Levinasian spiritual poverty, but I still need some way of providing for everyone. Development ethics offers one way. Ananta Giri approaches the problem of providing for everyone's material needs through economic self-determination. My analysis shows that the problem with Giri's approach is that he does not account for the Levinasian spiritual poverty underlying self-determination - the need for relation to the Other. Incorporating Levinasian spiritual poverty into socio-economic conversations can influence laws respecting the material poor in the full light of their humanity to influence a more just society.

Funding: This research received no external funding.

Acknowledgments: Some of this material was encouraged as a result of participation in the National Endowment for the Humanities (NEH) Summer Seminar for College \& University Teachers: "Emmanuel Levinas on Morality, Justice, and the Political" held at SUNY at Buffalo, Buffalo, NY, USA, 17-21 July 2017, directed by Richard A. Cohen and James McLachlan, with the assistance of Jolanta Saldukaityte. Any views, findings, conclusions, or recommendations expressed in this publication do not necessarily reflect those of the National Endowment for the Humanities. 
Conflicts of Interest: The funders had no role in the writing of the manuscript, or in the decision to publish the results.

\section{References}

Cohen, Aryeh. 2015. Justice, Wealth, Taxes. Journal of Religious Ethics 43: 409-31. [CrossRef]

Galetti, Dino. 2015. The Grammar of Levinas' other, Other, autrui, Autrui: Addressing Translation Conventions and Interpretation in English-language Levinas Studies. South African Journal of Philosophy 34: 199-213. [CrossRef]

Giri, Ananta Kumar. 2005. Power and Self-Cultivation: Aesthetics, Development Ethics and the Calling of Poverty. Asian Journal of Social Science 33: 46-61. [CrossRef]

Levinas, Emmanuel. 1969. Totality and Infinity: An Essay on Exteriority. Translated by Alphonso Lingis. Pittsburgh: Duquesne University Press.

Levinas, Emmanuel. 1978. Otherwise than Being or Beyond Essence. Translated by Alphonso Lingis. Dordrecht: Kluwer Academic Publishers.

Levinas, Emmanuel. 1987. The Ego and the Totality. In Collected Philosophical Papers of Emmanuel Levinas. Translated by Alphonso Lingis. Dordrecht: Martinus Nijhoff, pp. 25-45.

Levinas, Emmanuel. 1993. Outside the Subject. Translated by Michael B. Smith. Stanford: Stanford University Press. Levinas, Emmanuel. 1999. Alterity and Transcendence. Translated by Michael B. Smith. New York: Columbia University Press.

Levinas, Emmanuel. 2012. Difficult Freedom: Essays on Judaism. Translated by Sean Hand. Baltimore: The Johns Hopkins University Press.

(C) 2018 by the author. Licensee MDPI, Basel, Switzerland. This article is an open access article distributed under the terms and conditions of the Creative Commons Attribution (CC BY) license (http:/ / creativecommons.org/licenses/by/4.0/). 